\title{
Mobilne aplikacije - korisna inovacija u šumarstvu?
}

\author{
Kruno Lepoglavec, Matija Landekić, Marijana Kanižaj, Hrvoje Nevečerel, Mario Šporčić
}

\begin{abstract}
Nacrtak - Abstract
Razvojem i napretkom mobilne tehnologije promijenila su se gledišta u prikupljanju, obradi $i$ interpretaciji različitih terenskih podataka u svim strukama, pa tako i u šumarstvu. U obavljanju stručnih šumarskih poslova mobilne aplikacije dosada nisu zamijenile tradicionalne šumarske instrumente i postupke. Međutim, na tržištu se pojavljuje sve veći broj aplikacija koje su namjenski razvijene za šumarstvo ili koje se osim u drugim područjima također mogu koristiti i za obavljanje nekih šumarskih zadaća. S tim u vezi, u ovom se radu daje pregled mobilnih aplikacija koje je moguće primijeniti u šumarstou. Prikazane aplikacije odabrane su, uz postavljene kriterije, pretraživanjem digitalnih servisa Google Play i App Store. Nakon opisa namjene i načina rada odabranih aplikacija posebno su istaknuta njihova glavna obilježja te pozitivne i negativne strane svake pojedine aplikacije. Cilj je rada procijeniti u kojoj mjeri mobilne aplikacije doista mogu biti korisna inovacija u šumarstou. Prikazom odabranih aplikacija pružaju se spoznaje o tome je li u šumarstou moguća profesionalna primjena mobilnih aplikacija.
\end{abstract}

Ključne riječi: ICT, mobilne aplikacije, inovacije, šumarstvo

\section{Uvod - Introduction}

Informacijsko-komunikacijske tehnologije (ICT) danas uvelike utječu na sve sfere čovjekova rada i života. One su postale nezamjenjiv dio poslovanja i važan su strateški čimbenik razvoja gospodarskih sustava i društva u cjelini. Područja rada u koja te tehnologije još nisu prodrle vrlo su malobrojna, a među mnoge prednosti koje tvrtke ostvaruju njihovom primjenom ubraja se smanjenje troškova poslovanja, ubrzavanje administrativnih poslova, poticanje i unapređenje procesa odlučivanja, jačanje konkurentnosti, povećanje produktivnosti, ugodniji, uspješniji i djelotvorniji rad (Mihanović 2016). Žugaj i dr. (2004) kao koristi koje organizacije ostvaruju od ICT-a navode: transformaciju nestrukturiranih procesa $\mathrm{u}$ rutinske transakcije, brzo i lako prenošenje informacija na velike distancije, smanjenje ili zamjenu ljudskoga rada, pružanje detaljnih informacija i kompleksne analitike za neki proces, omogućavanje promjene redoslijeda zadataka i njihovo jednovremeno obavljanje, razmjena znanja i ekspertiza te podrobno praćenje statusa zadataka, inputa $\mathrm{i}$ outputa.
Imajući na umu navedeno, ubrzani tehnološki razvoj promijenio je živote ljudi, načine poslovanja i mogućnosti obavljanja određenih zadataka, odnosno pribavljanja određenih usluga. Kao najčešće korišteni ICT današnjice pritom svakako možemo istaknuti tehnologiju pametnih telefona (smartphone) i mobilne aplikacije. U suvremenom svijetu gotovo svaka osoba posjeduje mobilni telefon, a broj i upotreba aplikacija za mobilne telefone (i prijenosna računala) posljednjih se nekoliko godina svakodnevno povećava. Mobilne su aplikacije dostupne na svim telefonima iz kategorije tzv. pametnih telefona i jedan su od najbrže rastućih segmenata svjetskoga mobilnoga tržišta. Njihova namjena varira, počevši od osnovnih funkcionalnosti mobilnih telefona kao što su razgovor i slanje poruka, preko korištenja zabavnih sadržaja, informiranja, kupovine na internetu i sl., pa sve do profesionalne primjene i rješavanja specifičnih zadaća $u$ različitim područjima poslovanja. Mnoge mobilne aplikacije posebno su razvijene za određena područja te su vrijedna inovativna pomagala koja se primjenjuju u prometu, turizmu i ugostiteljstvu, obrazovanju, bankarstvu, zdravstvu i dr. 
U šumarstvu su mobilne aplikacije relativno novija tehnološka inovacija. U obavljanju stručnih poslova upotreba aplikacija nije raširena i one dosada nisu zamijenile tradicionalne šumarske instrumente i uređaje, odnosno postupke. Većina danas na tržištu dostupnih aplikacija vezanih uz šumarstvo pretežito je namijenjena za (neprofesionalnu) primjenu na razini osobnoga informiranja, izobrazbe $\mathrm{i}$ sl. Takve su, na primjer, aplikacije za prepoznavanje biljnih vrsta, ptica, kukaca i sl., kao što su PlantNet, Leafsnap, Mushrooms, BirdID, Entomologas i dr. (Kanižaj 2019). Međutim, osim njih pojavljuje se i određeni broj aplikacija koje su ponajprije razvijene isključivo za primjenu u šumarstvu (Sokolar 2016, Kanižaj 2019). S tim u vezi, u ovom će se radu dati kratak pregled mobilnih aplikacija koje je moguće primijeniti u šumarstvu. Cilj je rada procijeniti u kojoj mjeri mobilne aplikacije doista mogu biti korisna inovacija u šumarstvu. Prikazom odabranih aplikacija pružit će se spoznaja o tome je li u šumarstvu moguća profesionalna primjena mobilnih aplikacija.

U šumarstvu, jednako kao i u drugim poslovnim sustavima, razvoj i primjena mobilnih aplikacija predstavlja inovaciju u proizvodnji i poslovanju. Međutim, šumarstvo kao niskotehnološki sektor tradicionalno karakterizira niska razina inovacija (Rametsteiner i dr. 2005), a dosadašnja su istraživanja potvrdila relativno nepovoljno stanje inovacija te nisku inovacijsku kulturu u hrvatskom šumarstvu (Šporčić i dr. 2014, 2018). S obzirom na to da su inovacije neosporno važna i aktualna tema modernoga poslovanja, njihova primjena i razvoj neizostavno su nužni i u šumarskom sektoru. Tema je ovoga rada stoga vezana uz prikaz odabranih mobilnih aplikacija kao inovativnih pomagala u šumarstvu koja možda mogu zamijeniti specijalizirane šumarske instrumente visoke cijene (zbog male serije). Prednost je ovakvih aplikacija što pametne telefone posjeduje sve više ljudi te su aplikacije lako dostupne (često besplatne), jednostavne za upotrebu, atraktivno dizajnirane i brze u pružanju traženih informacija. $\mathrm{Na}$ osnovi pregleda odabranih aplikacija u ovom radu moći će se ocijeniti njihova glavna obilježja te mogućnosti njihove operativne primjene u šumarstvu.

\subsection{Značenje i uloga inovacija u šumarstvu Importance and role of innovation in forestry}

Važnost je inovacija prepoznata na razini zajedničke politike Europske unije (EU) te je inovacija glavna sastavnica strategije »Europa $2020 \ll$, jednako kao i prethodne "Lisabonske strategije (ekonomska strategija rasta Europske unije). U skladu s tim inovacija je jedan od pet eksplicitnih ciljeva, a kreiranje prijateljskoga okruženja za inovacije (Unija inovacija) jedna od sedam temeljnih inicijativa europske strategije rasta (EC 2010). Prema tomu okvirni program EU-a za istraživanja - Obzor 2020 usredotočen je na inovacije, uz ostvarenje i daljnje razvijanje Europskoga istraživačkoga prostora (EC 2011). S naporima koji se ulažu u jačanje inovacijskih aktivnosti EU nastoji ostvariti pametan, održiv i uključiv rast te osigurati dugoročnu konkurentnost europskoga gospodarstva na svjetskom tržištu.

U kontekstu šumarske politike Ministarska konferencija o zaštiti šuma u Europi (Ministerial Conference on the Protection of Forests in Europe, MCPFE), još je 2003. godine prihvatila Bečku rezoluciju o »Ekonomskoj održivosti potrajnoga gospodarenja šumama (Economic Viability of Sustainable Forest Management) koja izražava potrebu da se »unaprijedi konkurentnost šumarskoga sektora promicanjem inovacija i poduzetništva među svim relevantnim dionicima« (MCPFE 2003). U rezoluciji iz Madrida 2015. godine »Šumarski sektor u središtu zelene ekonomije" (Forest sector in the center of Green Economy) MCPFE ponovno naglašava neophodnu obvezu »promicanja inovacija i istraživanja (...) osnaživanjem razvoja inovacijske kulture« te »omogućavanje jednako razvoja politike i inovacija za dugoročnu konkurentnost cjelokupnoga šumarskoga sektora" (MCPFE 2015). U novoj Strategiji EU-a za šume i sektor koji se temelji na šumama (EC 2013) također se višekratno ističe važnost inovacija u odgovoru šumarstva na izazove i prilike koji se postavljaju pred sektor.

U šumarstvu se inovacije razvijaju, jednako kao i u drugim industrijama, radi poboljšanja konkurentnosti šumarskih tvrtki, nacionalnoga šumarstva ili cjelokupnoga šumarskoga sektora nasuprot drugim dionicima na tržištu. Šumarstvo je istodobno, zajedno s priželjkivanim inovacijama u sektoru, izravno uključeno u razvoj ruralnih područja kao jedan od glavnih ciljeva EU-a. Globalni procesi i promjene pritom također neizbježno utječu i na šumarsko-drvni sektor, koji skupa s vlastitim tehnološkim, organizacijskim, proizvodnim, uslužnim, rekreacijskim i drugim inovacijama mora postati konkurentniji i profitabilniji na globalnoj razini.

Na razini pak poduzeća za mnoge uspješne tvrtke inovacije su ključni čimbenik njihova rasta i razvoja. Osnovni razlog zašto tvrtke inoviraju leži u poboljšanju njihove poslovne izvedbe, npr. povećanjem potražnje ili smanjenjem troškova. Djelovanje inovacija na poslovanje tvrtke može se kretati od učinaka na prodaju i tržišni udio do promjena u produktivnosti i djelotvornosti. Inovacije također mogu 
unaprijediti izvedbu poduzeća tako da povećaju njihovu sposobnost inoviranja (OECD 2005). Važni utjecaji na razini nacionalnih gospodarstava i pojedinih gospodarskih grana su (pozitivne) promjene $u$ međunarodnoj konkurentnosti i ukupnoj proizvodnosti, prelijevanje znanja iz inovacija u tvrtkama i povećanje ukupne količine znanja u mrežama (Rametsteiner i dr. 2005).

Inovacije se danas drže temeljem uspješne poslovne prakse i pokretačkom snagom suvremene ekonomije. Ekonomska su istraživanja pritom potvrdila inovacije kao ključni čimbenik ekonomskoga rasta, konkurentnosti i zapošljavanja (Rametsteiner i Weiss 2006). To je učinilo inovacije, kreativnost i inventivnost sve važnijim te nezaobilaznim pitanjem $\mathrm{u}$ analizama učinkovitosti i postignuća tvrtki, industrija, regija i nacionalnih gospodarstva.

\section{Problematika i ciljevi istraživanja Research scope and objectives}

Neke stručne zadaće u šumarstvu danas je moguće provoditi upotrebom pametnih telefona i odgovarajućih mobilnih aplikacija. Pametni je telefon mobilni uređaj koji ima svojstva osobnoga digitalnoga asistenta (PDA) i mobilnoga telefona. Današnji se modeli mogu opisati kao mali multimedijski uređaji. Sadrže kamere, ekrane osjetljive na dodir, pristup internetu, navigaciju pomoću GPS-a, Wi-Fi i brojne druge mogućnosti, što omogućuje njihovu široku primjenu u svakodnevnom životu (Podrug 2017).

Aplikacija se može definirati kao primjenjivi program, tj. računalni program dizajniran za pomoć korisnicima u obavljanju jednoga ili više određenih zadataka. Mobilna aplikacija, prema informatičkim stručnjacima, najčešće se spominje kao vrsta aplikacije ili softver dizajniran za rad na mobilnim uređajima poput pametnoga telefona ili tablet računala (Kanižaj 2019). Mobilne aplikacije danas bilježe stalan rast preuzimanja u različitim područjima zabave, informiranja i svakodnevnoga poslovanja. Glavni su razlozi dostupnost (jednostavne su za instalaciju i često besplatne), neprestano jačanje bežične mreže i procesne snage uređaja kojima su namijenjene (dlanovnici i pametni telefoni) te jednostavnost korisničkoga sučelja (ekrani osjetljivi na dodir) (Podrug 2017).

Zbog nagloga razvoja mobilnih uređaja mobilne aplikacije postaju sve važniji dio tržišta softvera pri čemu se uočavaju i aplikacije koje su namjenski razvijene za šumarstvo ili se osim u drugim područjima također mogu koristiti i za obavljanje nekih šumarskih zadaća. Prema podacima STATISTA-e količina različitih aplikacija u lipnju 2019. godine na servisu Google Play dosegla je broj od 2700 000, na App Store 2000 000, Windows store 700000 i na Amazon appstore 500000 (www.statista.com). Svi digitalni servisi za skidanje aplikacija pritom imaju pretežno besplatne aplikacije te je omjer oko $95 \%$ prema $5 \%$ u korist besplatnih aplikacija. Broj je mobilnih uređaja u Hrvatskoj prema HAKOM-u (Hrvatska regulatorna agencija za mrežne djelatnosti) premašio 4700 000, što je više od ukupnoga broja stanovnika u državi (www.hakom.hr).

Istodobno s razvojem i napretkom mobilne tehnologije promijenila su se gledišta u prikupljanju, obradi i interpretaciji različitih terenskih podataka u svim strukama, pa tako i u šumarskoj struci. Ono što nas $\mathrm{u}$ šumarstvu gura prema upotrebi mobilnih aplikacija jest sve veći broj moguće primjenjivih aplikacija nasuprot dosad korištenih instrumenata, uređaja i softvera, koji su usko specijalizirani samo za jednu operaciju prikupljanja i obrade podataka. Glavni je nedostatak takvih specijaliziranih šumarskih instrumenata njihova visoka nabavna cijena (male serije), što posebno dolazi do izražaja ako se instrumenti nabavljaju za neintenzivne izmjere, pa su oni zbog toga značajan dio vremena zapravo izvan upotrebe.

S obzirom na navedeno, ciljevi ovoga rada vezani su uz pregled mobilnih aplikacija koje je moguće koristiti u šumarstvu. Prikazom odabranih aplikacija želi se ukazati na mogući doprinos takvih rješenja $\mathrm{u}$ unapređenju šumskoga gospodarenja te na mogućnost njihova uvođenja i profesionalne primjene u hrvatskom šumarstvu. Glavne su zadaće u radu pri tom:

$\Rightarrow$ odabrati odgovarajuće mobilne aplikacije na digitalnim servisima Google Play i App Store

$\Rightarrow$ opisati namjenu, način rada i glavne značajke odabranih aplikacija

$\Rightarrow$ istaknuti pozitivne i negativne strane svake pojedine aplikacije preko iskustva korisnika

$\Rightarrow$ procijeniti mogućnost profesionalne primjene pojedine aplikacije pomoću predložene skale primjenjivosti aplikacija.

Prikazom mobilnih aplikacija kao inovativnih pomagala $\mathrm{u}$ radu šumarskih stručnjaka nastoji se upozoriti na mogućnosti i potrebu primjene novih (ICT) tehnologija u šumarstvu. Na primjeru deset različitih mobilnih aplikacija analiziranih $u$ radu pokazuje se prijeko potreban pristup šumarskoga sektora u poticanju inovacija te uvođenju novih, originalnih $\mathrm{i}$ inovativnih rješenja $\mathrm{u}$ prikupljanju, 
obradi i interpretaciji različitih terenskih podataka. Svrha je rada pružiti informacije o mogućnostima primjene mobilne tehnologije šumarstvu te istodobno razviti svijest o važnosti inovacija, potrebi izgradnji inovacijske kulture te nužnosti novih tehnologija u šumarstvu.

\section{Metoda rada-Methods}

Pretraživanjem mobilnih aplikacija dostupnih na digitalnim servisima Google Play i App Store odabrane su aplikacije prikazane $\mathrm{u}$ rezultatima rada. Kao kriteriji za odabir aplikacija, uz njihovu namjenu, tj. primjenjivost $u$ šumarstvu, uzeti su ovi parametri:

$\Rightarrow$ cijena - težište na besplatnim aplikacijama

$\Rightarrow$ broj preuzimanja - učestalije preuzimane (downloadane) aplikacije

$\Rightarrow$ jezik aplikacije - prednost aplikacija na engleskom i/ili hrvatskom jeziku

$\Rightarrow$ ocjene i recenzije korisnika - aplikacije s većim brojem povratnih informacija korisnika.

$\mathrm{Na}$ opisani način odabrano je deset mobilnih aplikacija koje uglavnom zadovoljavaju sve ili većinu postavljenih kriterija. Nakon kratkoga opisa namjene i načina rada odabranih aplikacija prikazana su njihova glavna obilježja te posebno istaknute pozitivne i negativne strane svake pojedine aplikacije. Glavna obilježja promatranih aplikacija obuhvatila su njihovu cijenu, jezik sučelja, broj preuzimanja, prosječna ocjena i recenzije korisnika, podržani operativni sustav (Android, iOS), zemlju razvoja aplikacije i godinu objave. U preglednoj tablici sa skupnim podacima o aplikacijama dodatno su pridane opisne ocjene o mogućoj profesionalnoj primjeni određenih aplikacija u šumarstvu prema predloženoj skali autora rada sa stupnjevima: 1) neprimjenjivo, 2) slaba primjenjivost, 3) dobra primjenjivost, 4) vrlo dobra primjenjivost, 5) izvrsna.

\section{Rezultati - Results}

Provedenim proučavanjem tržišta mobilnih aplikacija, mogućih u primjeni u šumarskoj struci, izdvojeno je deset mobilnih aplikacija uz kratak opis prema parametrima definiranim u metodama rada.

\section{Aplikacija MOTI}

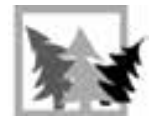

Aplikacija služi za izmjeru visine stabla, izmjeru broja stabala po hektaru, temeljnice po hektaru, obujma po hektaru, udaljenosti od točke interesa. Moguće je korištenje na Android i iOS platformi.

$$
\begin{aligned}
& \Rightarrow \text { besplatna } \\
& \Rightarrow \text { ocjena } 4,4 \\
& \Rightarrow \text { skidanja } 10000+ \\
& \Rightarrow \text { recenzije uglavnom pozitivne } \\
& \Rightarrow \text { englesko sučelje. }
\end{aligned}
$$

Pozitivne strane

$\Rightarrow$ precizna izmjera visine stabla pri dobroj preglednosti i kvalitetnom kamerom.

Negativne strane

$\Rightarrow$ preveliko odstupanje pri izmjeri udaljenosti, temeljnice i obujma. Za izmjeru potreban stativ za mobitel radi mirnoće i radi bolje preciznosti mjerenja.

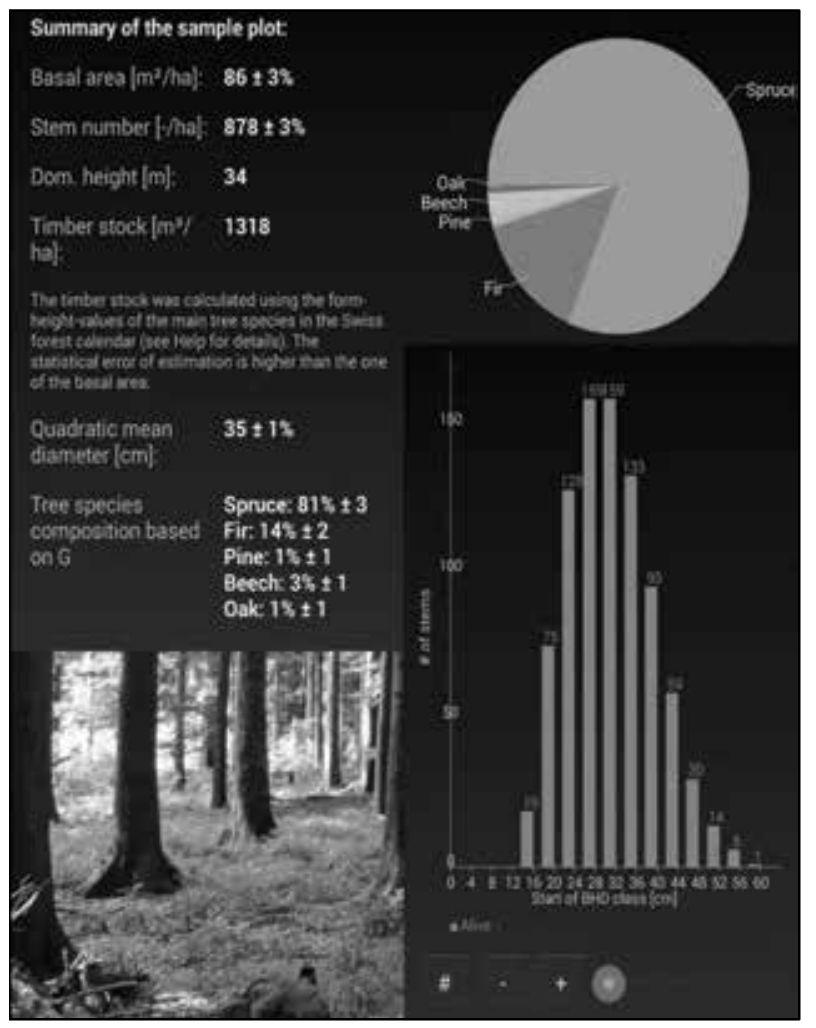

Slika 1. Obrada podataka u aplikaciji MOTI

Fig. 1 Data processing in the MOTI application

\section{Aplikacija IFOVEA $\left[\begin{array}{ll}1 & 1 \\ 2 & 3\end{array}\right]$}

Određuje broj trupaca u složaju te obujam drva na vrlo jednostavan i brz način. Aplikacija omogućuje automatsko prebrojavanje do 1000 trupaca u složaju, a optimizirana je za drvo promjera iznad $12 \mathrm{~cm}$. Moguće je korištenje na Android i iOS platformi. 
$\Rightarrow$ besplatna (Pro verzija je uz naknadu)

$\Rightarrow$ ocjena 3,8 (Pro verzija 4,6 )

$\Rightarrow$ skidanja $5000+$

$\Rightarrow$ recenzije pozitivne

$\Rightarrow$ hrvatsko i englesko sučelje.

Pozitivne strane

$\Rightarrow$ brza izmjera obujma i broja trupaca u složaju te pojedinačno, pozicija trupaca pomoću GPS-a.

Negativne strane

$\Rightarrow$ teško određivanje za promjer ispod $12 \mathrm{~cm}$ te nemogućnost točne izmjere za cijepano drvo.

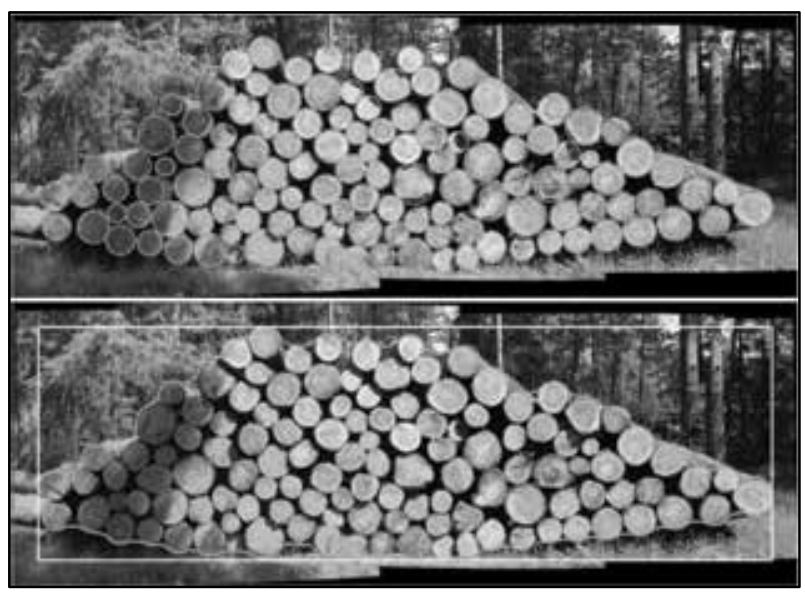

Slika 2. Prikaz zbrajanja obujma složaja u aplikaciji IFOVEA Fig. 2 Volume summation of timber stack in the IFOVEA application

\section{Aplikacija TIMBERPOLIS}

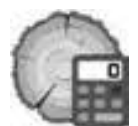

Kalkulator za drvo, za snimanje/zapise (trupci i rezana građa), upravljanje zalihama te baza podataka o komercijalnim tipovima drva. Moguće je korištenje na Android platformi.

$\Rightarrow$ besplatna probna verzija dva tjedna (Pro verzija je uz naknadu)

$\Rightarrow$ ocjena 4,2

$\Rightarrow$ skidanja 100 000+

$\Rightarrow$ recenzije pozitivne

$\Rightarrow$ hrvatsko i englesko sučelje.

Pozitivne strane

$\Rightarrow$ kalkulator obujma s 21 načinom mjerenja drva, pretvarači težine i obujma drva, oblovine i drvne građe, pretvarač mjernih jedinica, izrada barkoda i izvještaja, pozicioniranje pomoću GPS-a, fotografija trupaca.
Negativne strane

$\Rightarrow$ inventar na zalihama, pregled i ispis pripremljenih dokumenata i obrazaca te nove opcije i usluge dostupne samo $u$ Pro verziji nakon registracije (5 eura).

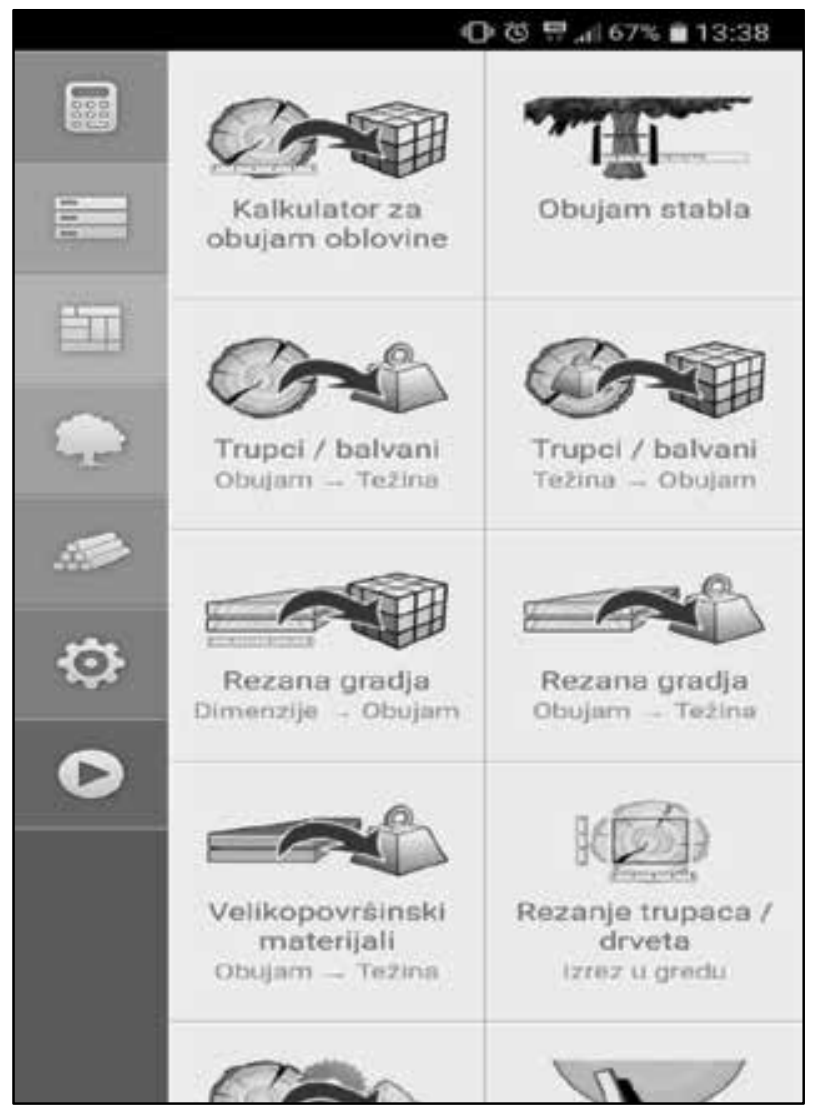

Slika 3. Izbornik aplikacije TIMBERPOLIS

Fig. 3 TIMBERPOLIS application menu

\section{Aplikacija ALTIMETER}

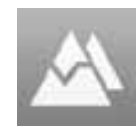

Mjeri nadmorsku visinu u bilo koje vrijeme i s visokom preciznošću određuje visinu ili koordinate te je moguć rad i bez pristupa internetu. Moguće je korištenje na Android i iOS platformi.

$\Rightarrow$ besplatna

$\Rightarrow$ ocjena 4,6

$\Rightarrow$ skidanja 1000 000+

$\Rightarrow$ recenzije uglavnom pozitivne

$\Rightarrow$ englesko sučelje.

Pozitivne strane

$\Rightarrow$ GPS-ova triangulacija satelita radi bez internetske veze, visoka točnost podataka, ako je internetska veza dostupna, ona sama kalibrira za poboljšanje točnosti. 
Negativne strane

$\Rightarrow$ određivanje otežano kod nedostupnosti internetske mreže i dovoljnoga broja satelita, velik broj oglasa.

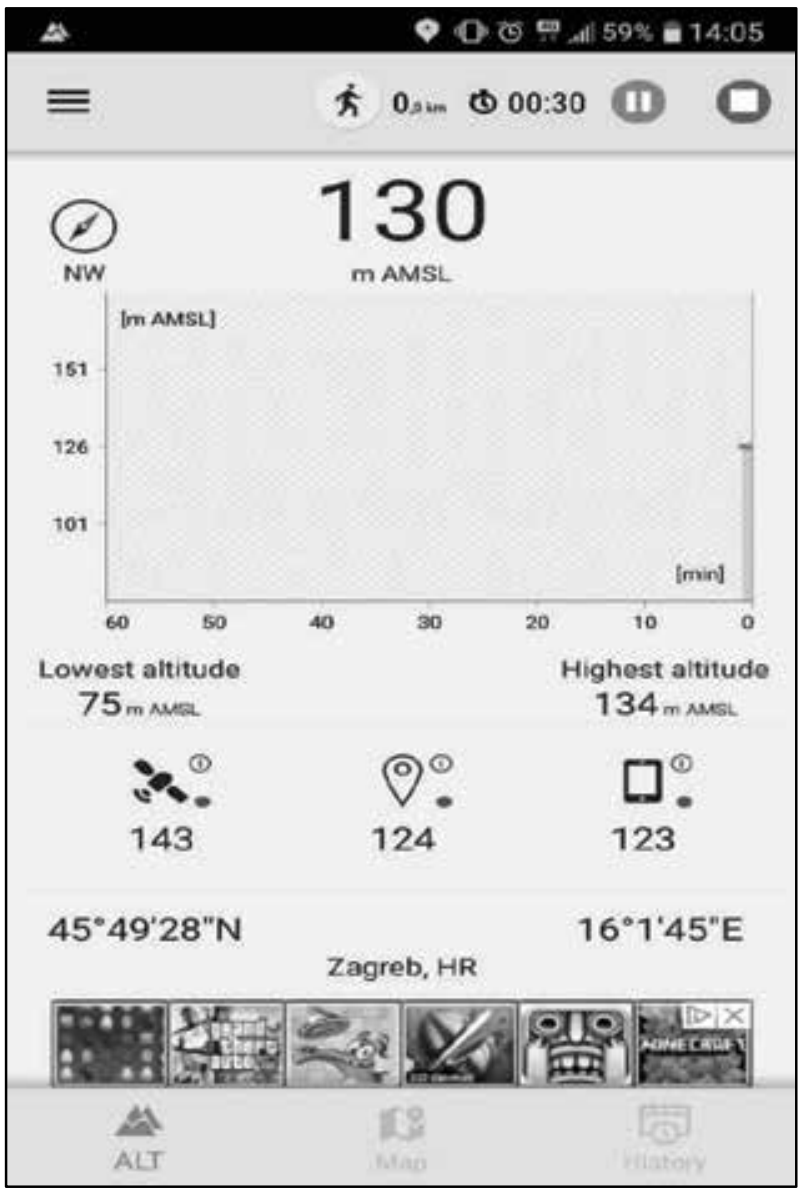

Slika 4. Prikaz nadmorske visine u aplikaciji ALTIMETER Fig. 4 Display of elevation in the ALTIMETER application

\section{Aplikacija MAP MEASURE}

Aplikacija za mjerenje duljina, površina i visinskih razlika između definiranih točaka. Moguće je korištenje na Android i iOS platformi.

$\Rightarrow$ besplatna

$\Rightarrow$ ocjena 4,4

$\Rightarrow$ skidanja 500 000+

$\Rightarrow$ recenzije pozitivne

$\Rightarrow$ englesko sučelje.

Pozitivne strane

$\Rightarrow$ jednostavno sučelje, osnovni elementi za definiranje površine $\mathrm{i}$ duljine $\mathrm{u}$ stvarnom mjerilu $\mathrm{s}$ odličnom točnošću. Prikaz u različitim mjernim jedinicama, jednostavno spremanje i slanje podataka.

Negativne strane

$\Rightarrow$ nedostatak dodatnih opcija, visoka osjetljivost na dodir prstom pri unosu točaka te loša mogućnost korekcije.

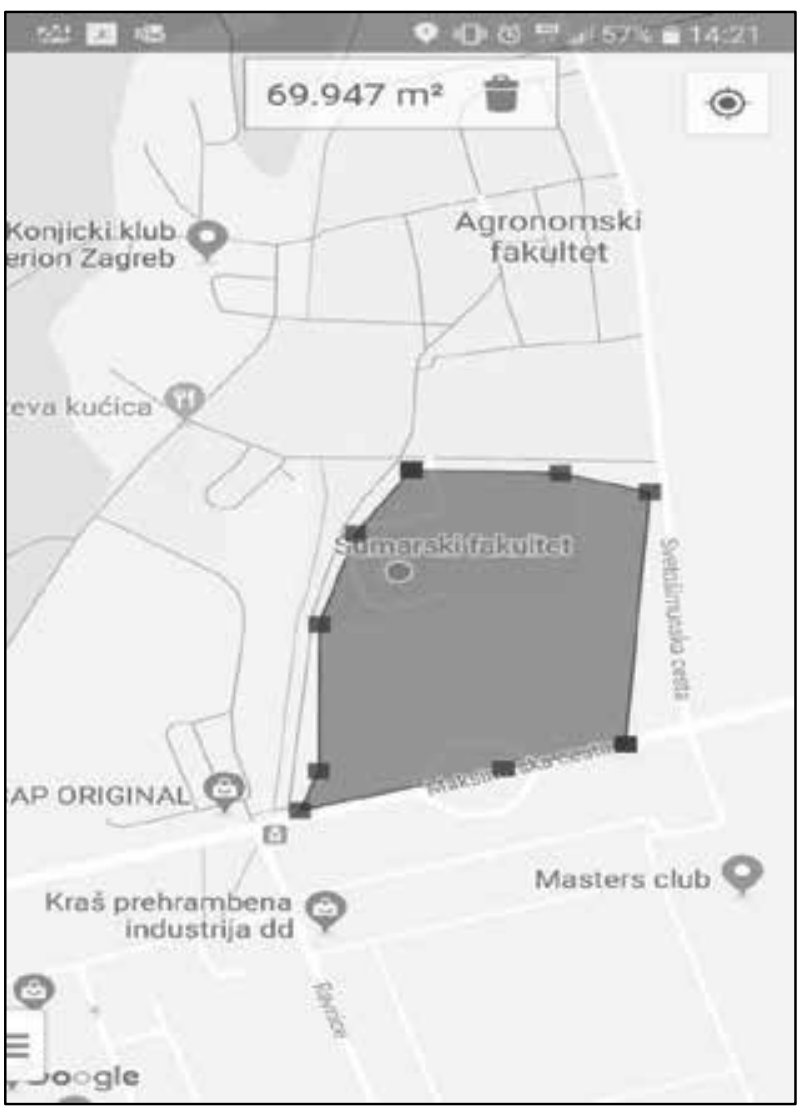

Slika 5. Izmjera površine u aplikaciji MAP MEASURE

Fig. 5 Surface measurement in the MAP MEASURE application

\section{Aplikacija A-GPS TRACKER}

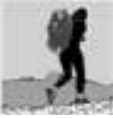

Tracker za teren koji koristi GPS mogućnosti mobilnoga uređaja. Ako je aktiviran, može snimati zapis čak i kad je telefon u stanju pripravnosti. Moguće je korištenje na Android platformi.

$\Rightarrow$ besplatna

$\Rightarrow$ ocjena 4,4

$\Rightarrow$ skidanja $500000+$

$\Rightarrow$ recenzije pozitivne

$\Rightarrow$ englesko sučelje.

Pozitivne strane

$\Rightarrow$ prihvatljiva točnost podataka, rad aplikacije i u standby modu mobilnoga uređaja, jednostavno 
sučelje te lagan prijenos snimljenih podataka $\mathrm{u}$ trenu preko poruke ili elektroničkom poštom.

Negativne strane

$\Rightarrow$ nedovoljan izbor podloga (topografskih karata), nemogućnost transformacije formata podataka $u$ samoj aplikaciji.

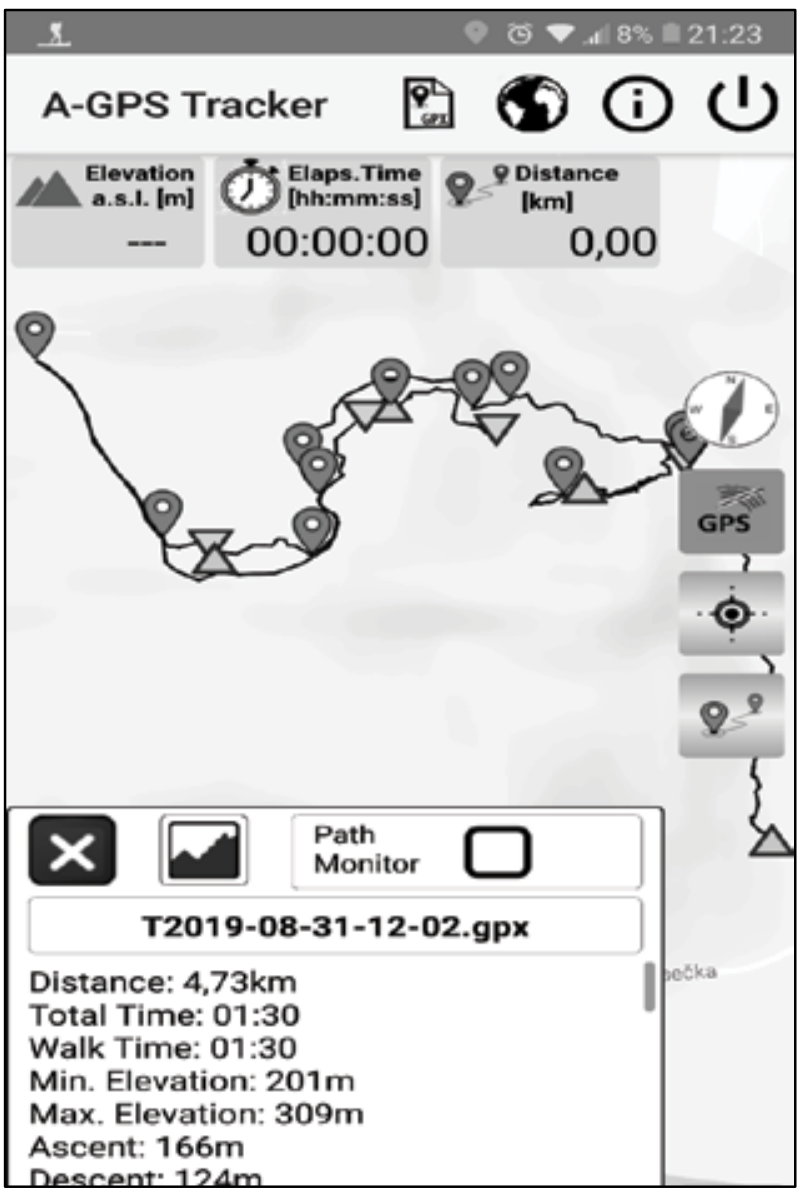

Slika 6. Snimak traga i točaka interesa u aplikaciji A-GPS TRACKER

Fig. 6 Trace record and points of interest in the A-GPS TRACKER application

\section{Aplikacija ALPINEQUEST}

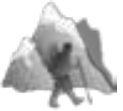

Cjelovito rješenje za sve aktivnosti na otvorenom i sport, uključujući planinarenje, trčanje, pješačke staze, lov, geocaching, off-road navigaciju i sl. Moguće je korištenje na Android i iOS platformi.

$\Rightarrow$ besplatna (plaćanje Pro verzije)

$\Rightarrow$ ocjena 4,5

$\Rightarrow$ skidanja 1000 000+

$\Rightarrow$ recenzije pozitivne

$\Rightarrow$ englesko sučelje.

\section{Pozitivne strane}

$\Rightarrow$ velik broj različitih digitalnih podloga/karata koje rade i u offline modu nakon skidanja karte, podržavanje lokalnih projekcija gotovo svih zemalja svijeta, topografske karte s mnogo detalja i ekvidistancije $10 \mathrm{~m}$.

Negativne strane

$\Rightarrow$ za snimanje traga potrebno kupovanje Pro verzije u iznosu od 8 eura.

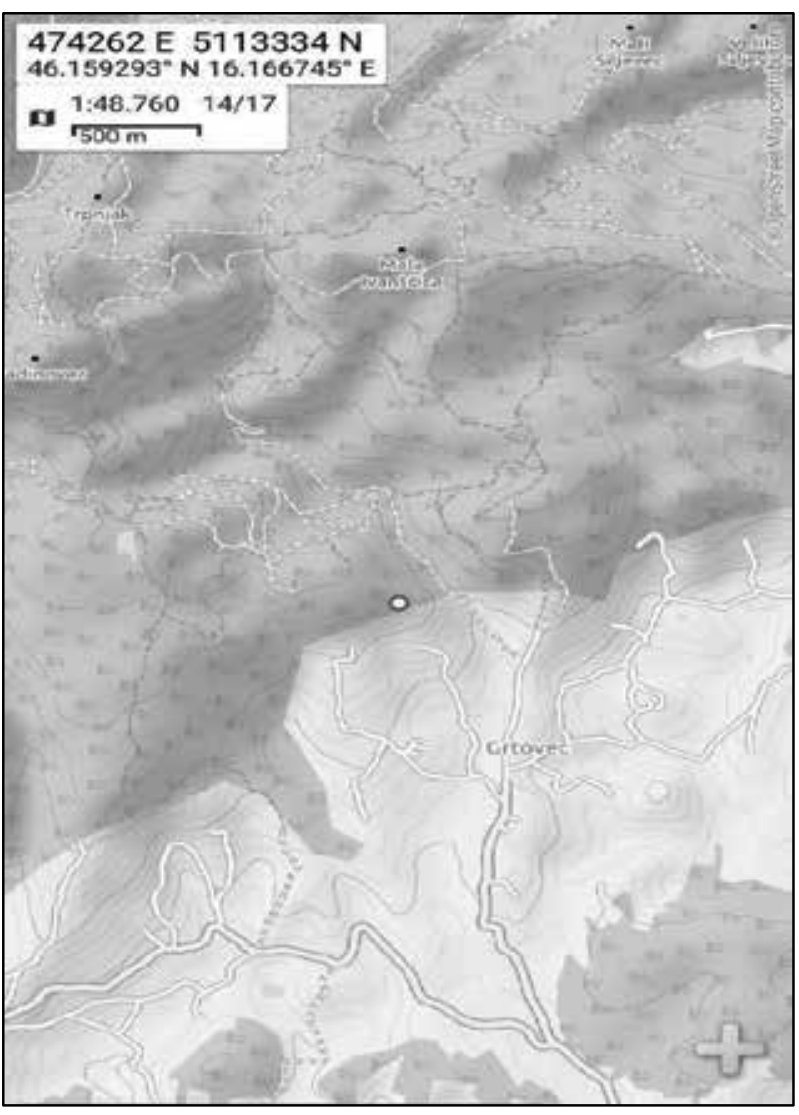

Slika 7. Prikaz topografske karte s pozicijom GPS-a u aplikaciji ALPINEQUEST

Fig. 7 View of topographic map with GPS position in the ALPINEQUEST application

\section{Aplikacija MAPIT GIS - Map Data Collector \& Measurements}

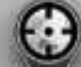

Profesionalan, samostalan, ekonomičan alat za mapiranje (GIS). Geodetski osmišljen kako bi povećao produktivnost korisnika u radu na terenu. Moguće je korištenje na Android platformi.

$\Rightarrow$ besplatna (plaćanje Pro verzije)

$\Rightarrow$ ocjena 4,2 
$\Rightarrow$ skidanja 100 000+

$\Rightarrow$ recenzije pozitivne

$\Rightarrow$ englesko sučelje.

Pozitivne strane

$\Rightarrow$ moguć rad s velikim brojem prijamnika GNSS za dobivanje centimetarske točnosti, velik izbor karata, mogućnost izvoza u više formata (gpx, shp, dxf, kml, csv i dr.), rad s atributnim tablicama.

Negativne strane

$\Rightarrow$ precizan rad ovisi o dobrom signalu GPS-a, za precizno snimanje potreban prijamnik GNSS, cijena Pro verzije 17 eura.

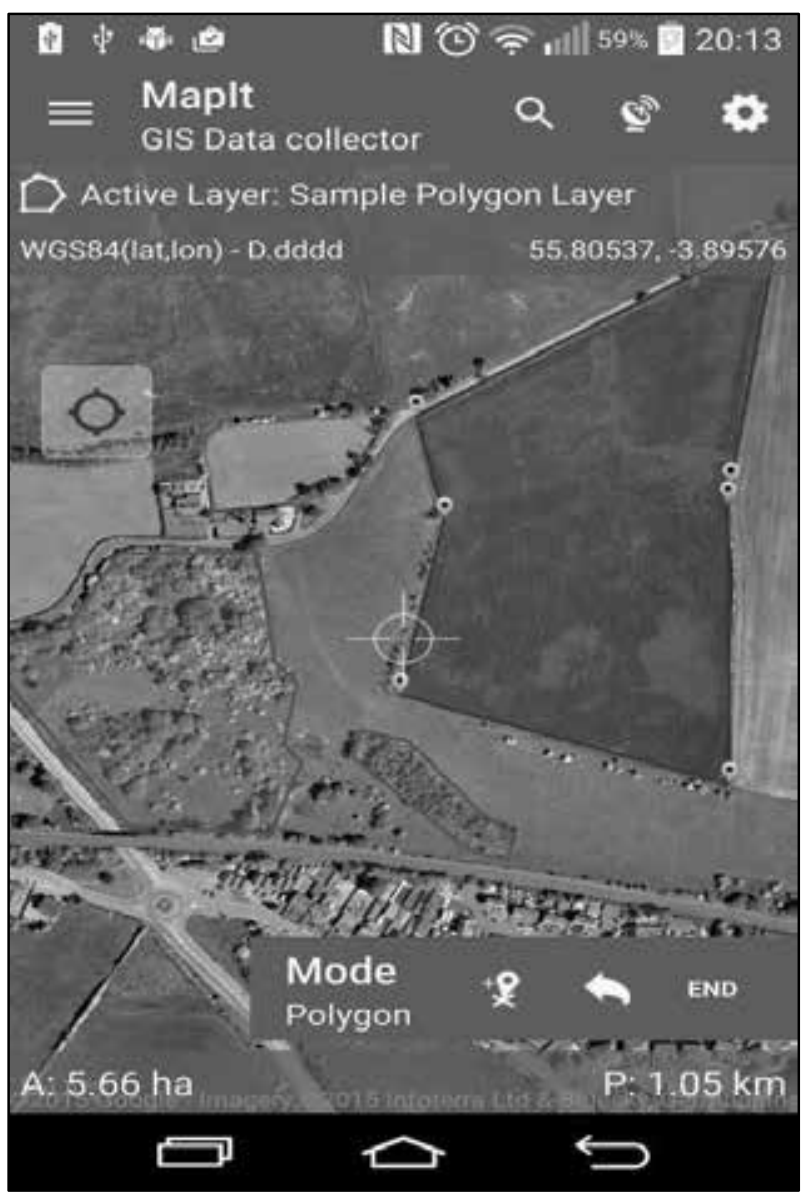

Slika 8. Kartiranje poligona u aplikaciji MAPIT GIS

Fig. 8 Polygon mapping in the MAPIT GIS application

\section{Aplikacija Pix4Dcapture}

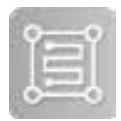

Pix4Dcapture pretvara dronove $\mathrm{u}$ profesionalni alat za mapiranje. U kombinaciji s fotogrametrijskim programom Pix4D Pix4Dcapture savršen je alat za automatsko snimanje slikovnih podataka - RGB, termički, za optimalne 3D modele i karte. Moguće je korištenje na Android i IOS platformi.

$\Rightarrow$ besplatna

$\Rightarrow$ ocjena 3,6

$\Rightarrow$ skidanja $100000+$

$\Rightarrow$ recenzije uglavnom pozitivne

$\Rightarrow$ englesko sučelje.

Pozitivne strane

$\Rightarrow$ jednostavno sučelje, mogućnost automatskoga i manualnoga upravljanja dronom, spremanje misija za kasnije ponavljanje, programska podrška za kasniju obradu podataka.

Negativne strane

$\Rightarrow$ loša vidljivost kamerom pri ručnom upravljanju, nemogućnost finoga namještanja postotka (pomaci su namještanja po $5 \%$ ) preklopa fotografija kod automatskih misija.

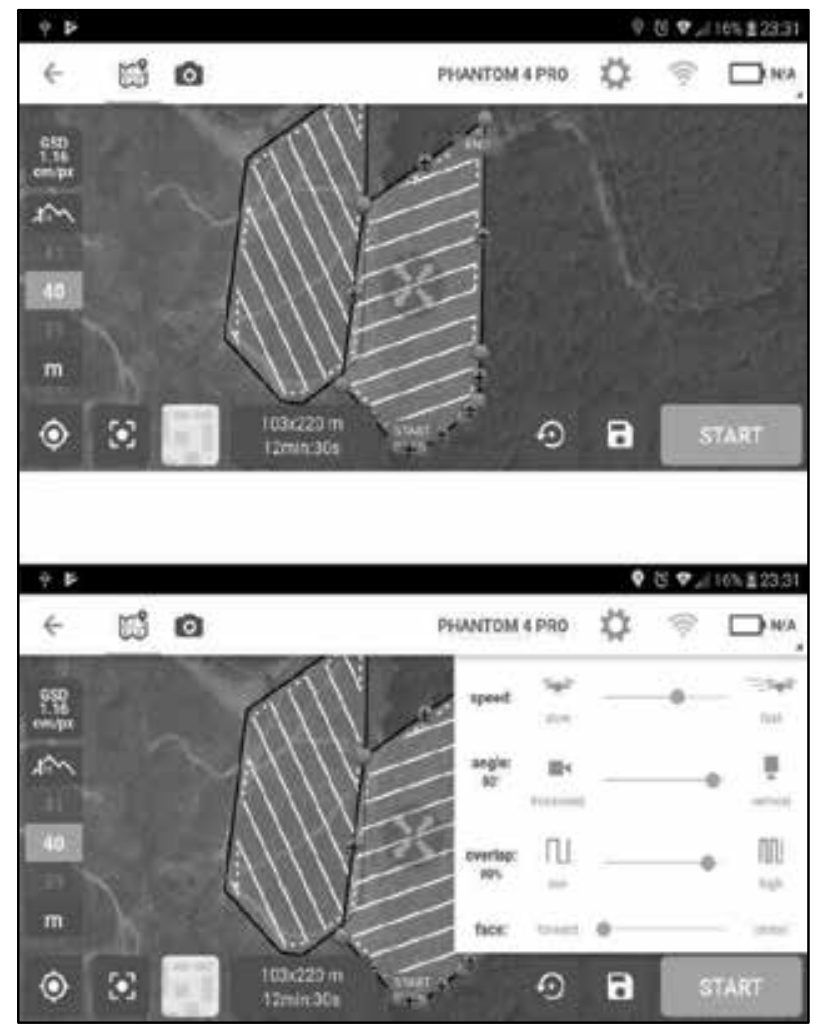

Slika 9. Izrada misije leta drona u aplikaciji Pix4Dcapture Fig. 9 Creating a drone flight mission in the Pix4Dcapture application

\section{Aplikacija LITCHI for DJI}

Litchi je savršen alat za automatsko i manualno snimanje dronom postavljajući misije preko točaka 

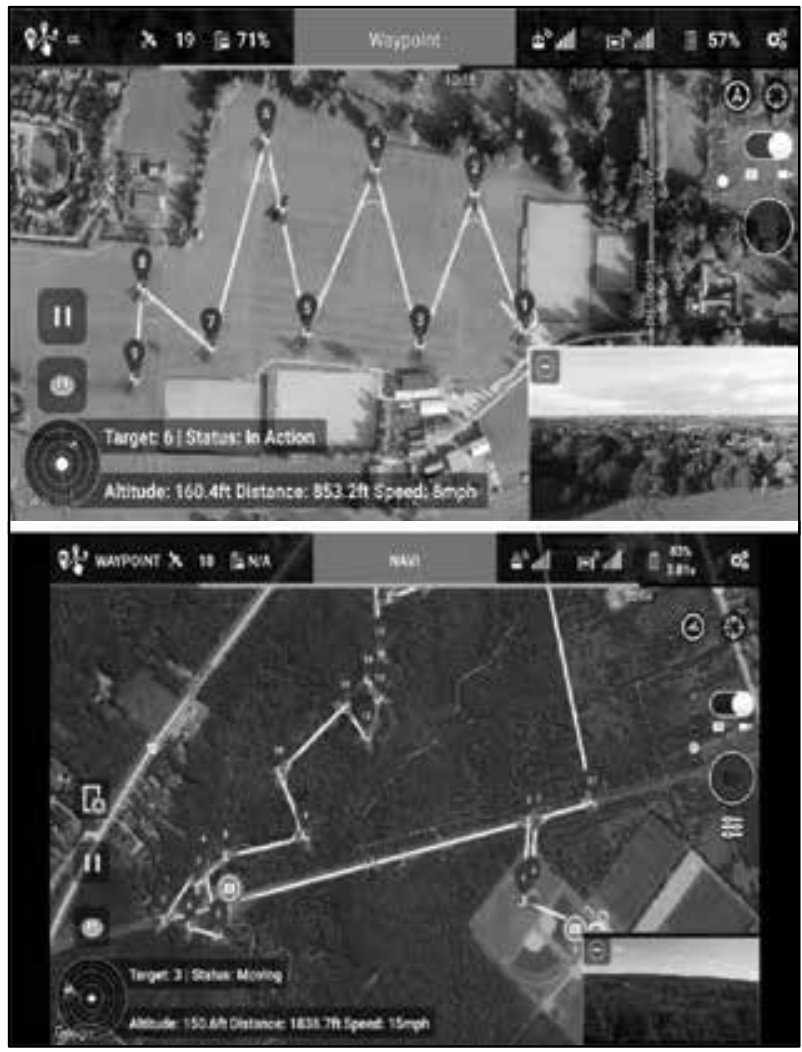

Slika 10. Izrada plana letenja pomoću putnih točaka (točaka interesa) u aplikaciji LITCHI for DJI

Fig. 10 Creating a flight plan using waypoints (POIs) in LITCHI for DJI

interesa (waypoints). Moguće je korištenje na Android i iOS platformi.

$\Rightarrow$ besplatna

$\Rightarrow$ ocjena 3,9
$\Rightarrow$ skidanja 100 000+

$\Rightarrow$ recenzije pozitivne

$\Rightarrow$ englesko sučelje.

Pozitivne strane

$\Rightarrow$ velik broj opcija letenja i snimanja površine ili pojedinih stabala, izrada misija i preko mrežne stranice, dobra preglednost tijeka misije i kretanja drona, mogućnost snimanja videa, potpuna kontrola nad dronom u svakom trenutku, fino namještanje visine i operacija rada.

Negativne strane

$\Rightarrow$ potrebno je uložiti značajan trud za definiranje većih misija površinski preko točaka interesa.

Podaci o aplikacijama pregledno su prikazani u tablici te su im pridružene opisne ocjene o mogućoj profesionalnoj primjeni $u$ šumarskoj struci prema vlastito definiranoj skali autorâ ovoga rada.

\section{Zaključci - Conclusions}

$\mathrm{Na}$ temelju testiranja odabranih aplikacija $\mathrm{u}$ stvarnim uvjetima te potrebe za prikupljanjem terenskih podataka u hrvatskom šumarstvu svakako se može napraviti opći zaključak da je primjena mobilnih aplikacija nužna u šumarstvu u prvom redu radi smanjenja visokih troškova zastarjele i dotrajale opreme, ali i radi veće produktivnosti rada. Razvoj izabranih aplikacija prikazanih u ovom radu tekao je u dobrom smjeru i kod nekih je aplikacija vidljiva uključenost šumarskih stručnjaka u njihovo osmišljavanje, što svakako treba primijeniti prilikom razvoja svake aplikacija koja je specifične namjene za šumarstvo, ali i za neke aplikacije širega spektra korisnika.

Tablica 1. Osnovni podaci o aplikacijama s pridijeljenom ocjenom realne primjenjivosti u šumarstvu

Table 1 Basic data about applications with assigned assessment of real applicability in forestry

\begin{tabular}{|c|c|c|c|c|c|c|c|}
\hline $\begin{array}{c}\text { Aplikacija } \\
\text { Application }\end{array}$ & $\begin{array}{c}\text { Operativni sustav } \\
\text { Operative system }\end{array}$ & $\begin{array}{c}\text { Jezik } \\
\text { Language }\end{array}$ & $\begin{array}{c}\text { Cijena } \\
\text { Price }\end{array}$ & $\begin{array}{c}\text { Zemlja razvoja } \\
\text { Country of origin }\end{array}$ & $\begin{array}{c}\text { Godina objave } \\
\text { Release year }\end{array}$ & $\begin{array}{c}\text { Ocjena } \\
\text { korisnika } \\
\text { User ratings }\end{array}$ & $\begin{array}{c}\text { Profesionalna } \\
\text { primjenjivost } \\
\text { Professional } \\
\text { applicability }\end{array}$ \\
\hline MOTI & Android, iOS & eng. & besplatna & Švicarska & 2013. & 4,4 & slaba - low \\
\hline IFOVEA & Android, iOS & eng. + hrv. & plaćanje Pro verzije & Njemačka & 2016. & 4,6 & dobra - good \\
\hline TIMBERPOLIS & Android & eng. + hrv. & plaćanje Pro verzije & Slovačka & 2015. & 4,2 & izvrsna - excellent \\
\hline ALTIMETER & Android, iOS & eng. & besplatna & Poljska & 2016. & 4,6 & vrlo dobra - very good \\
\hline MAPS MEASURE & Android, iOS & eng. & besplatna & Njemačka & 2014. & 4,4 & izvrsna - excellent \\
\hline A-GPS TRACKER & Android & eng. & besplatna & Italija & 2016. & 4,4 & izvrsna - excellent \\
\hline ALPINEQUEST & Android, iOS & eng. & plaćanje Pro verzije & Velika Britanija & 2014. & 4,5 & vrlo dobra - very good \\
\hline MAPIT GIS & Android & eng. & plaćanje Pro verzije & Švicarska & 2014. & 4,2 & vrlo dobra - very good \\
\hline Pix4Dcapture & Android, iOS & eng. & besplatna & Švicarska & 2015. & 3,6 & izvrsna - excellent \\
\hline LITCHI for DJI & Android, iOS & eng. & besplatna & Velika Britanija & 2015. & 3,9 & izvrsna - excellent \\
\hline
\end{tabular}




\section{K. Lepoglavec i dr.}

Pojedine aplikacije od korisnika zahtijevaju višu razinu informatičkoga znanja pa bi hrvatsko šumarstvo, a pritom mislimo ponajprije na Šumarski fakultet Sveučilišta u Zagrebu, Hrvatski šumarski institut, Hrvatsku komoru inženjera šumarstva i drvne tehnologije (HKIŠDT), Hrvatske šume d.o.o. i dr., trebalo nastojati provoditi izobrazbu o radu s aplikacijama u sklopu stručnih predavanja HKIŠDT-a, fakulteta, veleučilišta i srednjih škola preko radionica, tečaja i nastavnih predmeta i sl.

Prilikom analiziranja i odabira aplikacija za testiranje i ocjenjivanje primijećen je nedostatak kvalitetnih rješenja koja bi unutar jedne aplikacije objedinjavala više operacija koje se provode $u$ šumarstvu te postoji potreba za izradom takvih aplikacija, što bi šumarskim stručnjacima uvelike olakšalo terenski i uredski posao.

Sva iskustva stečena testiranjem aplikacija i dobiveni rezultati navode na općeniti zaključak da je prošlo vrijeme čekanja i skeptičnosti za uvođenje novih tehnologija $u$ hrvatsko šumarstvo te da se $u$ tom smislu nikako ne smije dopustiti da šumarstvo (p)ostane začelje inženjerskih struka.

\section{Literatura - References}

European Commision (EC), 2010: Europe 2020 strategy. Available at: http://ec.europa.eu/europe2020/documents/related-document-type/index_en.htm

European Commision (EC), 2011: Horizon 2020 - The EU Framework Programme for Research and Innovation. Available at: https://ec.europa.eu/programmes/horizon2020/en

European Commision (EC), 2013: EU Forest Strategy. Available at: https://ec.europa.eu/agriculture/forest/strategy_en

Kanižaj, M., 2019: Inovativne aplikacije i alati u šumarstvu. Diplomski rad, Šumarski fakultet Sveučilišta u Zagrebu, 30 str.

MCPFEE, 2003: Vienna Resolution 2 „Enhancing Economic Viability of Sustainable Forest Management in Europe". $4^{\text {th }}$ Ministerial Conference on the Protection of Forests in Europe, 28-30 April 2003, Vienna, Austria. Available at:
Mobilne aplikacije - korisna inovacija u šumarstvu? (79-89)

http://www.foresteurope.org/docs/MC/MC_vienna_resolution_v2.pdf

MCPFEE, 2015: Madrid Ministerial Resolution $1 »$ Forest sector in the center of Green Economy«. $7^{\text {th }}$ Ministerial Conference on the Protection of Forests in Europe, 20-21 October 2015, Madrid, Spain. Available at: http://www. foresteurope.org/sites/default/files/ELM_7MC_2_2015_ MadridResolution1_GreenEconomy_adopted.pdf

Mihanović, A., 2016: Stanje, trendovi i mogućnosti informacijsko-komunikacijskih tehnologija u hotelskoj industriji. Završni rad, Ekonomski fakultet Sveučilišta u Splitu, 39 str.

OECD, 2005: Guidelines for Collecting and Interpreting Innovation Data. Oslo Manual, $3^{\text {rd }}$ edition. OECD, Statistical Office of the European Communities, Luxembourg, 10 Nov 2005, 162 str.

Podrug, I., 2017: Mogućnosti primjene mobilnih aplikacija u nastavi prirode i biologije. Educatio Biologiae 3(1): 165-176.

Rametsteiner, E., G. Weiss, 2006: Innovation and innovation policy in forestry: Linking innovation process with systems models. Forest Policy and Economics 8: 691-703. https://doi.org/10.1016/j.forpol.2005.06.009

Rametsteiner, E., G. Weiss, K. Kubeczko, 2005: Innovation and entrepreneurship in forestry in central Europe. Leiden Brill Academic Publishers, 179 str.

Sokolar, S., 2016: Primjenjivost »Moti« aplikacije za mobilne telefone u izmjeri šuma. Završni rad, Šumarski fakultet Sveučilišta u Zagrebu, 26 str.

Šporčić, M., S. Posavec, M. Landekić, T. Pentek, T. Poršinsky, K. Lepoglavec, 2014: Development and implementation of innovations in Croatian forestry. Proceedings of JOINT $5^{\text {th }}$ Forest Engineering Conference (FEC) \& $47^{\text {th }}$ International Symposium on Forestry Mechanisation (FORMEC) »Forest Engineering: Propelling the Forest Value Chain«, Gerardmer, France, 23-26 September 2014, 8 str.

Šporčić, M., M. Landekić, A. Đuka, M. Bakarić, 2018: Development and promotion of Innovation in Forestry - Innovation awarding programs and situation in Croatia. Works of the Faculty of Forestry, University of Sarajevo 1: 79-98.

https://www.statista.com/topics/1729/app-stores/

https://www.hakom.hr/default.aspx?id=9411 


\section{Abstract}

\section{Mobile Applications: Useful Innovation in Forestry?}

With the development and advancement of mobile technology, approach to collection, processing and interpretation of various field data in all professions, including forestry, has changed. In performing professional forestry work, mobile applications have not replaced traditional forestry instruments and procedures so far. However, an increasing number of applications are emerging on the market that have been specifically developed for forestry or that, in addition to other areas, can also be used to perform some forestry tasks. In this regard, the paper provides an overview of mobile applications that can be used in forestry. The applications presented in this paper were selected based on set criteria by searching Google Play and App Store digital services. After describing the purpose and mode of operation of the selected applications, their main features were presented with the emphasis on the positive and negative sides of each individual application. The aim of the paper is to assess the extent to which mobile applications can truly be a useful innovation in forestry. The presentation of the selected applications provides insights into whether professional use of mobile applications is possible in forestry.

Keywords: ICT, mobile applications, innovation, forestry

Primljeno (Received): 03. 10. 2019.

Prihvaćeno (Accepted): 16. 11. 2019.
Adrese autorâ - Authors' addresses:

Doc. dr. sc. Kruno Lepoglavec e-pošta: klepoglavec@sumfak.hr Doc. dr. sc. Matija Landekić * e-pošta:mlandekic@sumfak.hr Doc. dr. sc. Hrvoje Nevečerel e-pošta: hnevecerel@sumfak.hr Prof. dr. sc. Mario Šporčić e-pošta: sporcic@sumfak.hr Šumarski fakultet Sveučilišta u Zagrebu Zavod za šumarske tehnike i tehnologije Svetošimunska 25

10000 Zagreb

HRVATSKA

Marijana Kanižaj, mag. ing. silv. e-pošta: marijana02041993@gmail.com Cvjetna 1

34334 Kaptol HRVATSKA

* Glavni autor - Corresponding author 
